\title{
from Another Perspective
}

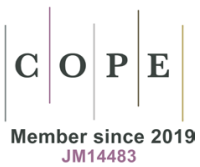

\section{S U M M A RY}

This essay with a clearly personal touch is a narrative anchored in cultural texts which deals with experiencing Venice in a multi-faceted way. Talking about his many years of wandering around the city (in the company of, for instance, Joseph Brodsky) and describing places and architectural details important to him, the author argues that especially the mediation of painting, which also documented the history of Venice, allows for a better understanding of the phenomenon of the city. This fusion of the two modalities of experience is also reflected in the structure of the text, which closes the reflection on the contemporary condition of the city and various threats which Venice has to face.

\section{Keywords}

space experience, Venetian culture and art, Joseph Brodsky

I was conceived in a modest Venetian hotel at the back of a railway station in the mid-1950s during my mother's love escapade with her professor. From that day on, my parents would return there every year and, after I reached the right age, they would take me with them, eagerly leaving our hometown of Florence for a few spring days.

When I was born, Venice on the lagoon had a population of 157,000 whereas today it has 51,000 inhabitants. And that is the main cause of many of its problems: the deserted city, which - especially in winter - is somewhat amazing when you sail through the Canal Grande at night because all the palazzi 
are dark. A large part of the houses in the centre are the holiday homes of people who neither live nor work in Venice, but only come to it from time to time.

Since my childhood, I have become accustomed to admiring Venice through great art: paintings and frescos by Bellini, Carpaccio, Titian, Tintoretto, Tiepolo... The images which anticipated my first visits to this city and the illumination that I actually found the same lights, the same potbellied clouds and the same pink sunsets that flame up the water. For me, Venice was, for a long time, a reality mediated by works of art: it never appeared to me in a raw form, but in a form already ordered, as part of culture. I had before my eyes The Death of Adonis by Sebastiano del Piombo (approx. 1512) from the Uffizi Gallery in Florence (where it was damaged during the night of 26 to 27 May 1993, during a mafia attack in via dei Georgofili, which resulted in five deaths), a painting depicting naked Venus, surrounded by her nymphs (also unclothed) and Cupid mourning the death of Adonis, who rests on the ground, killed by a boar. The scene seems to be located in a non-existent forest on the Venetian Isola di San Giorgio: the Doge's Palace and St Mark's Basilica can be seen on the other side of the canal. This painting has always seemed to me to be the saddest in the whole Gallery and the most stigmatised with death. Due to the common root of Venus/Venice (Venusia in Latin), this scene foreshadows in a way the end of life and the end of Venice's beauty.

When not in Milan, I have lived for many years in Venice in a house that used to be a boat storeroom at one of the palaces on the Canal Grande: from a window overlooking a side canal, you can see in the background peaceful water trams flowing and motorboats speeding away, which exacerbates the devastating movement of the waves. This makes me feel somewhat Venetian, too.

Nonetheless, vedute, or views, of Venice still fill me with slight melancholy. It is as if painters were better at capturing certain signals that often escape our attention among the problems of everyday life. I have in mind, for instance, small, wonderful pictures by Francesco Guardi (1712-1793), in the Gallerie dell'Accademia di Venezia, one of the most beautiful museums in the world, which is often overlooked by distracted tourists. Guardi's tiny figures, merely sketched, are more than a century ahead of the Impressionists. The views of Venice, so gloomy and ill, contradict the excesses of Canaletto's sugar-coated sweetness as they show, in bitter colours, decadence, often interspersed with ruins, which will shortly also coincide with the political demise of the city.

In Milan, in the Poldi Pezzoli Museum, there is a small painting by Guardi that is impossible to be forgotten. It is titled The Gondola on the Lagoon: all in grey and sky-blue, with the weak pinkish light of the city on the horizon line, separating the sky and the sea into equal parts, ghostly and uniform in colour. I owe the discovery of Guardi to Joseph Brodsky, a Russian poet who spent a longer period of time in Venice in 1989 at the expense of "Il Consorzio Venezia Nuova" (the one that was linked to the chaos of the MOSE System ${ }^{1}$ : a clear example of the heterogenesis of objectives). This stay

${ }^{1}$ The MOSE project (Moses, after the famous Venetian church) - the much delayed yet recently completed gate-system project aimed at protecting the city from flooding. 
resulted in Watermark, a wonderful book about Venice published in Italy in 1991 by the Adelphi publishing house under the Italian title Fondamenta degli incurabili. Brodsky claimed that he had been inevitably brought to Venice by fate, as he was born in 1940 in Leningrad, a city of sea and ice, where water and the sky seem to touch, just as they do in Venice. In addition to the book, he dedicated three of his most beautiful sonnets to the city on the lagoon, namely "Lagoon" (1973), "Venetian Stanzas I" and "Venetian Stanzas II" (1982): "Let me reiterate: Water equals time and provides beauty with its double. Part water, we serve beauty in the same fashion. By rubbing water, this city improves time's looks, beautifies the future. That's what the role of this city in the universe is." ${ }^{2}$

One beautiful windy afternoon we went with Brodsky and a friend of mine, a Venetian Russicist, Mauro Martini, to see Guardi, and having rushed through the other rooms (with only one mandatory stop in front of The Tempest by Giorgione), we found ourselves in a small side room and leaned before The Fire at San Marcuola (1789). The fire took place on 28 December that year and the painter, while preserving it on paper, was already seventy-eight years old. Based on these sketches from nature, Guardi later painted two pictures. The first version, clearer but with less raging flames and even more defenceless onlookers, can be found in the Alte Pinakothek in Munich. The Venetian painting is divided into four parallel horizontal parts. From the bottom to the top: a crowd of onlookers, seen from behind, in three-cornered hats and cloaks; the front of the flames; buildings already consumed by the fire; the sky covered in black heavy clouds. The sky takes up half the picture. "A real masterpiece!", Brodsky said, "it resembles the burning Ghetto in Warsaw and we, like them, look and do nothing." This image inevitably came back to my mind on 28 January 1996, when Teatro della Fenice burned like a match; then it was rebuilt quite quickly and stood "identical and in the same place." From an aesthetic and functional point of view, today's counterfeiting was perhaps not the best idea. In this case, the rescue operations were to some extent slowed down, as they say, by works connected with "clearing the canals." Massimo Cacciari, the Mayor of Venice, was the last to commission these absolutely essential conservation works: this has been evident in recent days, because the canals, as time passes, get logged like veins and water flows with greater difficulty. During the works, when dredgers were pulling out sand with all kinds of things to the surface, Mark Dion, a young American artist, began to collect, like an archaeologist, objects which the Venetians had thrown away into the water over the years (or which the water lifted during the tides): broken plates, dishes, pots and pans, parts of household appliances, toys, bottles, shells... He cleaned them and displayed them in showcases as if they were valuable museum exhibits. The result was something like Wunderkammer, a cabinet of curiosities, of what is marginal, showing the memory of Venetian canals. The initiative absorbed him so much that, in 1999, he began excavations on the banks of

\footnotetext{
${ }^{2}$ Joseph Brodsky, Watermark: An Essay on Venice, (London: Pengiun, 2013) 134-135. The Italian title, Fondamenta degli incurabili [The Embankment of the Incurables], was chosen by the author himself.
} 
the Thames, on a strip between the line of high tide and low tide. But, naturally, he did not find similar "miracles."

Whenever I can, I go to the San Michele cemetery on the isle of the dead situated on a lagoon north of Venice to visit the graves of Joseph Brodsky and Mauro Martini. Brodsky wanted to be buried (on 21 June 1997) next to Igor Stravinsky, Sergei Diaghilev, Ezra Pound and his life partner Olga Rudge (whom he met through Susan Sontag).

As Czesław Miłosz recalled in his poem titled "Czeladnik" [A Journeyman]: "I think of Venice coming back as a musical theme (...) / When having buried Joseph Brodsky / We were feasting at palazzo Moncenigo, just the same / In which Lord Byron had lived (...) / Venice sails away like a great ship of death / With a swarming crowd on its board turned into a spectre. / I said goodbye to her in San Michele at the graves of Joseph Brodsky and Ezra Pound. / Ready to welcome people still unborn, / For whom we will only be an enigmatic legend." ${ }^{3}$ In the half deserted evangelical sector, in the middle of the lawn, there is a simple tomb of Brodsky. Visitors, in accordance with the Russian custom, leave cigarettes and lighters, pens, stones and letters on it. Tomas Venclova, a Lithuanian poet and a friend of Brodsky and Miłosz, describes it in the following way: "Grass, stones. This is the island, / this is how the petrified wanderer listens / as silence grows above the bushes, / as a sphere responds dully to a sphere, / as waves cut rocks without mercy - / before consciousness awakens from apathy / not the blade of pain, and still / not a ship, water or human voices."4

When Mauro Martini was still alive (he died prematurely in 2005), we used to go together to put red roses on Brodsky's grave. On our way back, as if in the form of a ritual, we walked in silence along Fondamenta dei Mendicanti, which runs along the Hospital, to Campo S. Giovanni e Paolo, where we would sit down to drink a couple of spritzers to his memory in an old ice-cream parlour called "Rosa Salva," gazing at the beautiful windows overlooking the canal of Ennio Concina's house, an insightful and sulky researcher of Venetian and Byzantine architecture. His books helped us to understand how, through Byzantine culture, Russia is so strongly linked to Venice (it is not without reason that a collection of essays written in English and published by Brodsky in 1986 is titled "Flight from Byzantium"). ${ }^{5}$ Paul Muratoff (1881-1950), an eminent Russian art historian and the author of the monumental work titled Images of Italy ${ }^{6}$ (1911-1924) containing brilliant pages on Venice "immersed in its own eternal atmosphere of concentration" and on its art, wrote about it in the following fashion: "Venice looks to the East. For us, Russians, therefore, it is always the first and last stage of a journey to Italy. Never do we worry with such force about the uniqueness of the old journeys, and at the same time about the desire for new expeditions to

${ }^{3}$ Czesław Miłosz, "Czeladnik," in Druga przestrzeń (Krakow: Znak, 2002) 96. [Unless indicated otherwise, quotations in English were translated from Polish]

${ }^{4}$ Tomas Venclova. "Obrócone w ciszę," trans. Beata Kalęba. Zeszyty Literackie (2017), 115.

${ }^{5}$ Joseph Brodsky, "Flight from Byzantium," in Joseph Brodsky, Less Than One: Selected Essays (New York: Farrar, Straus, Giroux, 1986), 393-446.

${ }^{6}$ Paweł Muratow, Obrazy Włoch, trans. Paweł Hertz (Warsaw: PIW, 1972). 
places still unknown to us." In 1914, Muratoff was looking from the windows of a small Italian albergo in the Riva degli Schiavoni at the "Torino" steamboat, which was about to sail off to Piraeus and Constantinople: "it lured to come near with its glowing electric lights. Its dark body resting in the bacino of San Marco did not disturb the Venetian silence with a single sound." What seemed to disturb the peace of the city, as big passenger ships do every day, was a huge grey whale, which appeared in the spring of 2014 in the Grand Canal. The photo, published by many newspapers, was of course a forgery, as the signature confirms, featuring the name of the author: "A Whale in Venice, Italy. Photo Manipulation by Robert Jahns."

Rather than a fish, as Tiziano Scarpa suggested, Venice is a maze. That is exactly how Jacopo de' Barbari presented it in 1500 on his astounding bird's-eye-view Veduta cut in pear wood. An uninhabited, almost ghostly Venice, which, with its attention to detail, makes one's head spin. Its endless twistiness, highlighted on this old map, reminds me of the tracks of the Lido beach ball race. We marked out these routes by choosing the smallest and lightest child and pulling it like a plough to different sides on the sand back to the starting point, so as to close these winding tracks. Streets and bridges which often do not lead anywhere take me back to these games. When a person gets lost in Venice, traversing these twisted paths, they recover images of their own past.

There is a detail that Jacopo de' Barbari could not get out, and which is a frequent destination of my walks and a reference point for my memories. At a height of three metres, a white marble head is inserted in the high old wall that marks the perimeter of Corte Centani, at the embankment of Fondamenta Vernier dei Leoni, at the back of the Guggenheim Foundation. It looks like a ghost, or like Zephyr, who wanted to get out but got stuck when it was breaking through the bricks. It is the face of a chubby boy with his puffed cheeks and his lips tightened as if he was just about to blow.

Venice is full of fragments of old statues, built into the corners and walls of palaces. Like the figures of Moors from which the name of the embankment and the square is derived from. People bump into them unexpectedly, at eye level, like into cool and mysterious travellers.

These fragments show that much of Venice's beauty was created through plundering Eastern palaces. Every returning ship brought (and, what is more, it had to bring) statues, columns and floors to beautify the city. St. Mark's Basilica is the most evident example of a patchwork of theft, a conglomerate of styles and materials torn out of their context and detached from their original function, which makes it unique and impossible to imitate. On its left side there is a bas-relief showing Alexander the Great, lifted to the sky by a pair of griffins. A strange image indeed in a Christian church! Some even claim that the remains of the Macedonian leader are kept in St. Mark's Basilica instead of the relics of a saint (smuggled from Alexandria in Egypt by two Venetian merchants as it is depicted by the famous painting by Tintoretto in Gallerie dell'Accademia). St. Mark's Basilica

${ }^{7}$ Muratow, Obrazy Włoch, 123. 
(which was originally not the Basilica of Venice, but something like a chapel of the Doge's Palace) is a symbol of strong political power which uses religion - in the Byzantine fashion - as both the legitimacy and tool of their rule.

The Harlequin character of Venetian buildings makes the city cheerful. Whoever extolled the city as melancholic or, worse still, sad made a mistake (which is not difficult, as Venice is based on constant errors and misunderstandings). Just like Carnival, which has moved a little bit into the category of melancholy events, permeated by the subsequent Lent. The distinction is no longer clear: like in The Fight Between Carnival and Lent (1559) by Pieter Bruegel the Elder, where the whirl of characters does not allow for understanding where joking ends and where restraint begins. Venice, even covered by fog, in cold rain and with acqua alta, still emanates life. As if the waters of the lagoon (both fresh and salty) were mixing and hiding the differences, but in the end always revealing its most beautiful face (excellently presented by Canaletto and his nephew Bernardo Bellottotto), before the advent of the era of Guardi, who balanced these vedute with a bit of melancholy, and Turner with his dazzling light. It is clear what the poets had in mind when they wrote that Venice is woven from dream visions, and Gustaw Herling-Grudziński (1919-2000), a Polish and Neapolitan writer, the author of the mysterious short story titled Portret wenecki [Venetian Portrait], who admired "the city built of dreams" (...) "for this special relationship, I would like to say: for the marriage of dream with reality."

Last night, after I had read, among the various proposals to save the city in the face of recurrent floods, the project to "lift" it, I dreamt of about a thousand or so Zeppelin airships which pulled St Mark's Square into the air with ropes, as if it were an ashtray model, one of the kind sold in stalls, amidst the spectacle of confetti and pigeons and gulls escaping in panic. Venice is considered a romantic city. That is why millions of people in love come to it. Its streets and squares are swarming with people who look into each other's eyes, embrace each other and exchange affection. And then, they kiss passionately on bridges. And below, struggling to keep balance on folding chairs, dozens of painters and watercolourists immortalise, like members of the celebratory choir, the luminous crinkum-crankum of clouds and oblique lights on old stones. Of course, for someone who is lonely and sad, it is not a very pleasant sight to see the collective overflowing happiness. But all this joyful excess of love sometimes makes us forget that Venice is dying. Not only because it is corroded and eroded every day, crushed and trampled, strangled by falsity and trash. But also because of the provincial conviction of its many inhabitants that everything already happened and the future does not exist. This is a strange and not always consistent concept of protection that tries to keep modernity and, in fact, the course of life at bay from the city. It suffices to think, for example, of the rejection by the general public in 1953 (under the leadership of Antonio Cederna) of a beautiful palace designed by Frank Lloyd Wright for his friend Angelo Masieri,

${ }^{8}$ Gustaw Herling-Grudziński, Portret wenecki. Trzy opowiadania (Lublin: Wydawnictwo UMCS, 1995), 73. 
which could finally enrich the Grand Canal with a touch of modernity. But almost no one reacted when the arcades of Fondaco dei Tedeschi near Ponte di Rialto were devastated and turned into an ugly large luxury warehouse or when Ponte dei Sospiri was framed by vulgar advertising boards or when palazzi to be renovated were covered with really inappropriate light images. Venice cannot end up as something that resembles a flat and sad theatre decoration, intended to cover the gradual sinking that has been repeated with increasing frequency, as the recent dramatic days have shown.

How will Venice be saved? In 1940 Simone Weil wrote this, with a bit of hope and faith, in her unfinished theatrical text titled Venice Saved ${ }^{9}$ (published in Italian by the Adelphi publishing house and edited by Cristina Campo in 1987, the text went out of print and it was reprinted in 2016 by the Castelvecchi publishing house and edited by Domenico Canciani and Maria Antonietta Vito). There is a legend saying that in 1618 Venice was to be burned and destroyed by a Spanish conspiracy. It was saved by the remorse of a Jaffier, who betrayed his comrades: "God will not allow something so wonderfully beautiful to be destroyed. And who would like to harm Venice? The most relentless enemy would not have the conscience to do so. (...) A human being would not be able to create anything as beautiful as Venice. Only God. And since the human being is not alone capable of performing miracles, in order to come closer to God, they must do what they can: protect the beauty that God created."

\section{REFERENCES}

Brodsky, Joseph. "Flight from Byzantium." In Less Than One: Selected Essay, 393-446. New York: Farrar, Straus, Giroux, 1986.

Brodsky, Joseph. Watermark: An Essay on Venice. London: Pengiun, 2013.

Herling-Grudziński, Gustaw. Portret wenecki. Trzy opowiadania. Lublin: Wydawnictwo UMCS, 1995.

Miłosz, Czesław. “Czeladnik.” In: Druga przestrzen,, 96. Krakow: Znak, 2002. Muratow, Paweł. Obrazy Wtoch. Translated by Paweł Hertz. Warsaw: PIW, 1972. Venclova, Tomas. "Obrócone w ciszę." Translated by Beata Kalęba. Zeszyty Literackie (2017), 115.

Weil, Simone. Wenecja ocalona. Translated by Adam Wodnicki. Krakow: Austeria, 2007.

Francesco Matteo Cataluccio (1955) - studied philosophy and Polish philology in Florence and Warsaw. He is an author of many articles on the history and culture of Poland and Eastern Europe as well as an editor of the Italian edition of works by Witold Gombrowicz, Gustaw Herling-Grudziński or a collective Italian and Spanish edition of works by Bruno Schulz. He

${ }^{9}$ Simone Weil, Wenecja ocalona, trans. Adam Wodnicki (Krakow: Austeria, 2007), 68. 
is known to the Polish reader as an author of books such as Niedojrzatość, choroba naszych czasów [Immaturity: Disease of Our Time] (ZNAK, Krakow 2006), Jadę zobaczyć, czy tam jest lepiej. Niemalże brewiarz środkowoeuropejski [I'm Going to See if It's Better There] (ZNAK, Krakow 2012) and Czarnobyl [Chernobyl] (Czarne, Wołowiec 2013). His correspondence with Zbigniew Herbert was published in the volume Herbert. Studia i dokumenty [Herbert: Studies and Documents] edited by Piotr Kłoczowski (Warsaw, 2008). He received the Ryszard Kapuściński Award for Literary Reportage in 2013. E-mail: cataluccio.francesco@gmail.com 